\title{
Recent Advances in Methods for Recovery of Cenospheres from Fly Ash and Their Emerging Applications in Ceramics, Composites, Polymers and Environmental Cleanup
}

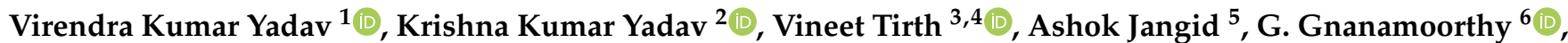 \\ Nisha Choudhary ${ }^{5}$, Saiful Islam ${ }^{7} \mathbb{1}$, Neha Gupta ${ }^{8}$, Cao Truong Son ${ }^{9, *}$ and Byong-Hun Jeon ${ }^{10, *(1)}$
}

check for updates

Citation: Yadav, V.K.; Yadav, K.K.; Tirth, V.; Jangid, A.; Gnanamoorthy, G.; Choudhary, N.; Islam, S.; Gupta, N.; Son, C.T.; Jeon, B.-H. Recent Advances in Methods for Recovery of Cenospheres from Fly Ash and Their Emerging Applications in Ceramics, Composites, Polymers and Environmental Cleanup. Crystals 2021, 11, 1067. https://doi.org/ $10.3390 /$ cryst11091067

Academic Editors: Maged F. Bekheet, Ulla Simon and Vladislav V. Kharton

Received: 17 June 2021

Accepted: 31 August 2021

Published: 3 September 2021

Publisher's Note: MDPI stays neutral with regard to jurisdictional claims in published maps and institutional affiliations.

Copyright: (c) 2021 by the authors Licensee MDPI, Basel, Switzerland. This article is an open access article distributed under the terms and conditions of the Creative Commons Attribution (CC BY) license (https:// creativecommons.org/licenses/by/ $4.0 /)$
1 Research and Development Centre, YNC Envis Pvt, Ltd., New Delhi 110059, India; yadava94@gmail.com

2 Faculty of Science and Technology, Madhyanchal Professional University, Ratibad, Bhopal 462044, India; envirokrishna@gmail.com

3 Mechanical Engineering Department, College of Engineering, King Khalid University, Abha 61411, Saudi Arabia; vtirth@kku.edu.sa

4 Research Center for Advanced Materials Science (RCAMS), King Khalid University Guraiger, Abha 61413, Saudi Arabia

5 School of Nanosciences, Central University of Gujarat, Gandhinagar 382030, India; ashok4483@gmail.com (A.J.); nishanaseer03@gmail.com (N.C.)

6 Department of Inorganic Chemistry, University of Madras, Guindy Campus, Chennai 600025, India; gnanadrdo@gmail.com

7 Civil Engineering Department, College of Engineering, King Khalid University, Abha 61413, Saudi Arabia; sfakrul@kku.edu.sa

8 Institute of Environment and Development Studies, Bundelkhand University, Jhansi 284128, India; nhgupta83@gmail.com

9 Faculty of Natural Resources and Environment, Vietnam National University of Agriculture, Hanoi 100000, Vietnam

10 Department of Earth Resources and Environmental Engineering, Hanyang University, Seoul 04763, Korea

* Correspondence: caotruongson.hua@gmail.com (C.T.S.); bhjeon@hanyang.ac.kr (B.-H.J.)

\begin{abstract}
Coal fly ash (CFA) is a major global pollutant produced by thermal power plants during the generation of electricity. A significant amount of coal fly ash is dumped every year in the near vicinity of the thermal power plants, resulting in the spoilage of agricultural land. CFA has numerous valueadded structural elements, such as cenospheres, plerospheres, ferrospheres, and carbon particles. Cenospheres are spherical-shaped solid-filled particles, formed during the combustion of coal in thermal power plants. They are lightweight, have high mechanical strength, and are rich in Al-Si particles. Due to cenospheres' low weight and high mechanical strength, they are widely used as ceramic/nanoceramics material, fireproofing material, and in nanocomposites. They are also used directly, or after functionalization, as an adsorbent for environmental cleanup-especially for the removal of organic and inorganic contaminants from wastewater. By utilizing this waste material as an adsorbent, the whole process becomes economical and eco-friendly. In this review, we have highlighted the latest advances in the cenospheres recovery from fly ash and their application in ceramics and wastewater treatment.
\end{abstract}

Keywords: coal fly ash; ceramics; cenospheres; alumino-silicate; ferrospheres

\section{Introduction}

Coal fly ash (CFA) is one of the major pollutants of the 20th and 21st centuries. It has drawn global attention regarding its safe management, optimized generation, and utilization [1]. Globally, a million tons of CFA are generated per year, in thermal power plants (TPPs), from the burning of pulverized coal, during the production of electricity [2]. The huge amount of generation of CFA leads to air, water, and soil pollution. Every year, a huge amount of CFA is dumped in the near vicinity of the TPPs, in fly ash 
ponds, which ultimately leads to water and land pollution. These fly ashes contain heavy metals, which can leach out once they contact water [3]. Besides heavy metals, CFA also contains minerals, such as magnetite, calcite, mullite [4], cristobalite, and silica [2]. These minerals contribute to the silica $(40-60 \%)$, alumina (20-40\%), and ferrous (5-15\%) that rely on the source and types of coal used [2].

Since TPP furnaces are operated at very high temperatures $\left(1000-1800{ }^{\circ} \mathrm{C}\right)$, the organic matter of coal becomes decomposed into a molten slag, which attains morphologically variable shape and size [5]. This variation leads to structurally different types of particles in CFA, namely, plerospheres, ferrospheres, and cenospheres (CS) [6]. The plerospheres are encapsulated particles that have numerous smaller particles within them, along with gases and minerals [7]. While, as the name suggests, ferrospheres are ferrous-rich spheres or "spherical particles" [8], and cenospheres are Al-Si rich spheres or "spherical particles" [2]. These Al-Si-rich particles are also known as aluminosilicate spheres or CFA microspheres [2]. As well as these spherical particles, there are varying amounts of irregular-shaped organic and inorganic carbon particles, i.e., unburned carbon soot and chars.

Among all the spherical particles, CS have been a focus in the field of ceramics, construction, lightweight materials, agriculture, etc., due to their unique physical and mechanical features. The word "cenospheres" is derived from the two Greek wordscenos, meaning "hollow", and spahira, meaning "spheres" [9]. These are spherical-shaped, mullite-rich $[4,10]$, inert, thin-walled hollow ceramic particles that have several trapped gases within them [11-15]. Their size falls in the range of 1-600 microns, and their total wt. fractions is about $1-2 \%$ in CFA [16]. From the literature, it is known that the water absorption capacity of porous CS is about 18 times higher than that of sand $[6,17]$. The hollow nature of CS is due to the presence of trapped gases [18]. Due to the hollow nature of CS, their density is near $2.3 \mathrm{~g} / \mathrm{cm}^{3}$, whereas the buoyancy of a CS is provided by its density. The bulk density of CS is around $400 \mathrm{~kg} / \mathrm{m}^{3}[19,20]$, and the true density is ca. $2.3 \mathrm{~g} / \mathrm{cm}^{3}$ [21]. Their high mechanical strength, high porosity, and thermal shock-resistance have encouraged scientists to use them in ceramics, the preparation of nanocomposites (decorating micron-sized CS with nanomaterials), and for environmental cleanup [22].

This review emphasizes the morphological, chemical, and physical properties of fly ash cenospheres. The purpose of this work was: (1) To provide all the methods applied, to date, for the recovery of cenospheres from coal fly ash, and (2) to reveal the recovery efficiency with all the applied methods. This work highlights the well-known and emerging applications of cenospheres. The main objective of this review was to provide state-of-art applications in the field of environmental cleanup and in ceramics and constructions.

\section{Morphological Properties of CFA Extracted Cenospheres}

Based on the morphology, viscosity of liquid composition of slag, and elemental composition, some investigators have classified the CS into two broad types-namely, nonmagnetic CS and magnetic CS. The formation of magnetic CS depend upon the melts of A-Si and Fe-Al-Si [9]. High viscosity type cenospheric particles have more tendency to trap gases and increase in diameter of the particle, resulting in the thinner shell with the complete absence of pores [23]. Whereas, in the case of a less viscous cenospheric material, the hot flue gas can pass through the material, due to the decreased viscosity. As a result, there are fewer chances of trapping the gases; hence, the diameter/shell thickness reduces to about 3-4 with a porous shell structure [23].

Certain cenospheres have high Fe deposition on their surface that exhibit magnetic properties, while others are mainly rich in $\mathrm{Al}$ and $\mathrm{Si}$ (along with $\mathrm{Na}$ and $\mathrm{Ca}$ ). In numerous pieces of literature, CS with small Fe deposition have been widely in the petroleum cracking, catalysis, ceramic, nanocomposites, and steel or iron-based industries [2]. Several investigators have considered the Fe deposition on CS as an important property, as based on this, only both nonmagnetic and magnetic CS can be identified and differentiated very easily [9], and widely used in the petroleum cracking, catalysis, ceramic, nanocomposites, 
and steel or iron-based industries [9]. Based on some physical parameters, i.e., texture, shell thickness, and shape, cenospheric particles are either transparent, grey, and dark type [24]. The former type of particle is thin-shelled, smooth-surfaced, grey type are translucent, porous, thick, and rough-surfaced [9]. While the dark-type CS have numerous perforations on their surface, their porosity is much greater than the grey CS. Dark CS scatters the light completely, which is passed through them and acts as an opaque particle. Ferrous-rich CS can be divided into two types: One having a porous shell, while the other with a spotty nonuniform surface, containing grey, black, brown, and white inclusions, along with dark black or brown spheres with a bright and smooth surface [25]. The Al content contributes a valuable role in the average size of a nonmagnetic CS, i.e., more Al equals higher mullite, and ultimately results in a decrease in the average diameter $[9,26,27]$.

CS can be divided into two main groups, based on their magnetic features, which are acquired by the presence of $\mathrm{Fe}_{2} \mathrm{O}_{3} / \mathrm{Fe}_{3} \mathrm{O}_{4}$ minerals in the shell [28]. The shell of CS is a complex, layered structure (which is covered by a nano-size film externally), and internally $[25,29]$ (which is $30-50 \mathrm{~nm}$ thick and contains $\mathrm{Fe}_{2} \mathrm{O}_{3}$ ). When the ferrous oxide percentage varies from 3 and $4 \mathrm{wt} . \%$ in the alumino-silicate glass, then two types of $\mathrm{Fe}^{3+}$ are present, i.e., single ions and nanoparticles with a diameter of 3 to $5 \mathrm{~nm}$. These particles consist of a superparamagnetic phase with a spinel structure whose sublattices are diamagnetically diluted with $\mathrm{Mg}^{2+}$ and $\mathrm{Al}^{3+}$ ions. CS, having about 7 wt.\% of $\mathrm{Fe}_{2} \mathrm{O}_{3}$ content, also involves a magnetic phase, based on defective magnetite [30].

Magnetic CS have heterogeneous regions of ferrospinels on their outer surface. An increase in the concentration of iron increases the crystallite size of the ferrospinel phase in the magnetic CS, and decreases the degree of iron substitution ( $\mathrm{Mg}$ and $\mathrm{Al})[9,26]$. In magnetic CS, shell thickness is independent of the shell composition. When the $\mathrm{Fe}_{2} \mathrm{O}_{3}$ content in magnetic particles (having porous shells and close average diameter values) increases by 4 to $21 \mathrm{wt}$.\%, it causes an increment in the number of spotty spheres (having a nonuniform surface) by 13-81 volume \% and in the number of dark globules (having smooth surface) up to 26 volume \% [25].

In general, CS size falls in the range of 20-300 microns, with a shell thickness of 1-18 microns, but the average size is 5-500 microns [31]. In comparison to the CFA particles, CS are much larger, and can vary from 5 to $500 \mu \mathrm{m}$ [15]. Ranjbar et al., 2017, said that the shell thickness of CS increases linearly with the increase in the diameter of the CS particle [9]. Ngu et al., 2007, reported that the ratios between wall thickness and diameter of ash cenospheres are limited between an upper bound of $\sim 10.5 \%$ and a lower bound of $\sim 2.5 \%$, irrespective of the ash cenosphere size [10]. When the coal is present in the molten slag, then the size of the cenosphere particle is governed by the temperature of the furnace of TPPs [13]. At a higher temperature, the molten slag of the coal is blustered into numerous smaller fragments, which are observed after the solidification of the cenosphere particles. Besides temperature, the particle size of a cenosphere in a TPPs is also governed by the chemical composition of the molten drop [13]. Several studies from the literature revealed that as the particle size of a cenosphere increases, Si and Al content decreasesbut there is a larger decrease in $\mathrm{Si}$, than the $\mathrm{Al}$ in the cenosphere because of the larger amount of Si present. Consequently, the alumina/silica ratio increases. As the particle size increases, then the $\mathrm{Al}$ content also increases. Due to the increase in $\mathrm{Al}$ content, the viscosity of the molten drop also increases, which stabilizes the large drop particles and prevents them from exploding into various smaller fragments. If particle size increases, then the alumina/silica ratio also increases, or if particle size decreases, the alumina/silica ratio decreases [15].

The formation of CS from pulverized coal is a very complex process that depends on the mineral matter, composition of coal, and combustion parameters of thermal power plants (TPPs) [12,14]. The cenosphere formation mechanism is similar to a glass blowing process. Firstly, coal is converted via molten slag at high temperatures, then secondly, molten slag starts flowing in the gas stream and undergoes rapid quenching [23]. Due to this rapid quenching, cooled molten slag falls into the formation of the sphere. After 
quenching, the particles are transformed into spheroids or spheres, and the minerals and gases present within them or in the nearby area become trapped inside the particles. These types of bubbles are responsible for the formation of CS, and could be either in multiple forms within the frozen particles or in single concentric forms-whose size in diameter is equivalent to the particles [20]. Because these particles interact for a very short time along with the influence of wettability parameters, numerous particles merge or coalesces into a large particle by maintaining the silicate and ferrous melted composition relationship between the two [20]. The formation of CS from pulverized coal in a TPP is justified by two hypotheses: One hypothesis suggests that condensed gases are formed because of the breakdown of the various organic and inorganic constituents of coal; thus, there is the evaporation of pore water in coal that becomes trapped in molten microspheres [20]. These trapped gases inflate the molten drop, increasing the size of the particles up to $500 \mu \mathrm{m}[13,15]$, and resulting in a spherical- and hollow-shaped particle. Whereas, the second hypothesis suggests that inside the furnace of TPPs, there are high-temperature zones where the molten ash droplets are first formed while being penetrated by the hot flue gas [23]. Once these particles are cooled down, these gases remain inside the spheres, which are called CS.

\section{Properties of Cenospheres Recovered from CFA}

Structurally, cenospheres are hollow spherical-shaped particles that resemble glass beads, micron-balloons, or hollow ceramic micron-sized spheres [32]. Their size is 5-500 microns [13], and an average size is $30 \mu \mathrm{m}$ to about $350 \mu \mathrm{m}[10,15]$. The cenospheric weight in a CFA comprises approximately $0.1-4.8 \%$ of the total weight of CFA [25], as shown in the literature.

There might be slight variation in the weight fractions from different parts of the world. As far as chemical compositions are concerned, CS contains elements, such as $\mathrm{Ca}, \mathrm{Mg}, \mathrm{K}$, $\mathrm{Na}, \mathrm{Ti}, \mathrm{Al}, \mathrm{Mg}, \mathrm{Si}, \mathrm{Fe}, \mathrm{C}$, and $\mathrm{O}$ [13], which may be present as different mineral phases [33]. Moreover, several investigators have also reported a trace of elements like V, Zr, Ba, Sr, S, P, and Rb. Strzałkowska and Adamczyk, 2019, reported all the above-mentioned elements in the CS recovered from three different TPPs (Dolna Odra, Opole, and Kazakhstan) [13]. Furthermore, Danish and Mosaberpanah, 2020, analyzed the chemical composition of CFA from 12 different TPPs, from various parts of the world, and found that all of them have $\mathrm{Si}, \mathrm{Al}$, and $\mathrm{Fe}$ as major elements, while $\mathrm{Ti}, \mathrm{Ca}, \mathrm{Mg}, \mathrm{Na}, \mathrm{S}$, and $\mathrm{Mg}$ were present in smaller quantities [14]. The common elements were $\mathrm{Al}, \mathrm{Si}, \mathrm{Fe}, \mathrm{O}$, and $\mathrm{Ca}$, whose composition may vary, but the presence of the other elements depend on the type of coal, source of coal, geographical origin, and furnace temperature during the burning of coal in the TPPs. When water or rain comes in contact with these toxic elements, it may leach out from there and may have a negative effect on the material [34,35].

Since CS have two surfaces, i.e., inner and outer, which are covered by a nano-thin film whose thickness is between $30-50 \mathrm{~nm}$ [30]. The inner surface is mainly composed of a glass of alumina and silica, and the skeleton is comprised of crystalline minerals like quartz, mullite, and magnetite [16]. Both of these surfaces make a shell composed of a crystalline phase and amorphous glass phase. The thickness of the crystalline phase is 2-30 microns, while for the amorphous glass phase, it is 50-90 microns [25]. The major crystalline phase is dominated by mullite, magnetite, calcite, cristobalite, feldspar, and hematite [36], which play a role in the morphology and elemental composition of $\mathrm{CS}$. The average gas pressure inside a CS is below one atm within the range of $0.172-0.227 \mathrm{~atm}$, which decreased in larger particles, since more gases would be required for expansion $[37,38]$. The stability of the hollow spheres is dependent on the equilibrium of surface tension forces on melt drops and intrinsic pressure of the internal hot gas [23]. The CS are bestowed with numerous physical properties like lightweight, low thermal conductivity (TC) [39], thermal shock-resistant [39], ultra-low density [31], highly porous [40,41], fire-proof [42], resistant to acid and bases [43], resistant to oxidation and corrosion [44], excellent mechanical strength [10], and protected from electromagnetic interferences [9,45-48]. The thermal shock-resistant properties in 
the CS are added from the mullite content [49], which is chemically inert. Furthermore, the porous nature of the CS enhances their water absorption capacity, thus it is considered a potential candidate as an absorbent for wastewater treatment and environmental cleanup [50].

\section{Methods Used to Recovery Cenospheres from CFA}

The recovery of CS from CFA is possible by both dry- and wet-based methods [51]. As the name suggests, the wet method involves a liquid media like water and or any organic solvent, whereas the dry-based method utilizes either air stream or size-based screening. Among all the techniques for recovery of CS from CFA most common methods are magnetic separation, sedimentation, flotation, or sink float method [21]. All these recovery methods are carried out in a separation tank which contains water $(1 \mathrm{~g} / \mathrm{cc})$ and acetone $(0.789 \mathrm{~g} / \mathrm{cc})$, which is fitted with agitation or stirring, and consequently, heavier particles settle down, while lighter particles float at the top. The dry-based method mainly uses air classifiers to separate CS particles [21,52].

\subsection{Wet Separation}

The sink float process is the most common method to separate the different components of CFA, followed by the gravity separation [53], are provided below in detail. Both of these methods involve a liquid medium, such as water and acetone, to separate the CS [54]. Manocha et al. reported the collection of four types of fly ashes from different power stations from the Gujarat region in India. They applied the sink flotation method for the separation of CS from all these four samples of fly ashes by using two different types of solvents having different densities. The recovery method helped in the extraction of about only $1 \%$ of the total composition of CS from the fly ashes by weight fractions [48].

The gravity separation method is one of the most preferred methods for the recovery of CS from CFA, due to its simplicity and common availability [55]. Since it is a wetbased method, it involves using liquid phases, such as water, acetone, etc., and works on hydraulic separation technique [21], whereas because is CS lighter in weight, it floats over the suspension. Furthermore, these suspended CS are collected by the pond skimming method [52,56]. Since this technique relies on the principle of physical parameters (density of solid and liquid particles, feed particle amount, buoyancy, porosity, and texture of the particles), so the efficiency of recovery of CS from CFA depends on all these factors. It could be better explained, for instance, a smooth surface particle will float faster than rough-surfaced particles, as smooth particles will have lesser interaction with the liquids, surfaces, and refinement cycles.

Beddu et al., 2021, used the sink-float technique to extract CS from CFA obtained from Malaysian thermal-based power plants. They designed a special rectangular reactor composed of acrylic. Here, the CS were extracted from CFA using the wet method (floatation/float and sink) [52].

Extraction of CS from lignite-based CFA (class C from Thailand) by sink-float technique was reported by Yoriya et al., 2019 [15]. Since his method involves a physical-method approach, a better quality of CS was achieved. This method was a wet separation method, where the used solvent was a mixture of acetone-water. Furthermore, the investigator used different ratios of water and acetone and observed the effect on the yield, morphology, and elemental composition of CS. They also concluded that calcium carbonate and $\mathrm{CaO}$ affected the recovery yield of CS. When the water-acetone ratio was $(0-50 \%)$, then the yield was significantly less, as the mixture had a lower density. Furthermore, when the liquid density was $>0.90 \mathrm{~g} / \mathrm{cc}$, then the CS yield also increased significantly. With the increase in acetone content, the density of the medium lowered, resulting in CS size of larger size. The Si and Al content gradually decreases with the decrease in the acetone content. The obtained CS was spherical in shape, while the CS obtained with high acetone $(80 \%$ and $100 \%$ ) have a clean surface. The recovery by this technique was reported to increase the separation efficiency, recovery yield, and quality of CS [15]. 
Petrus et al., 2011, used a float-sink test for the dry separation method, based on extracted CS. Their intention was to determine the quantity of cenospheric particles in the overflow and underflow products [57]. Liu et al. also extracted the CFA CS by using the flotation method. They used ethanol over here in the first step [58]. Alcala et al., 1987, reported the extraction of CFA CS from CFA by two different methods, i.e., flotation and simple sedimentation. Flotation experiments were carried out by using four different frothers as unique reagent addition. The buoyancy flotation technique (BFT) is based on the density of the CS. Therefore, cenospheres are usually concentrated using their natural buoyancy in water. Ali Kiani, 2016, reported the recovery of CS from CFA from various thermal power plants of Australia [59].

There are several reports where the skimming technique was applied for the recovery of CS from CFA. Two US patents, namely, US Patent No. 4121945A (1978) [60] and US Patent No. 4,652,433 (1987) [61], used the skimming technique. This technique mixes CFA with water to form a slurry, and then adds a frother, resulting in CS that is lighter than the skimmed water. However, both the patents reported certain drawbacks associated with this skimming technique. For instance, space, environmental concern, not fit for high lime containing CFA was some of the major ones. The advantages of this technique are that it can yield nearly $100 \%$ CS, and it avoids the agglomeration of CFA having high Ca content [62].

The efficiency of the wet separation techniques can also be increased by the clubbing of two or more different separation approaches like hydrodynamic gravitational separation, grain-size classification, and magnetic separation [15,21]. One of the most important advantages of wet separation is that by altering the recovery process, it is possible to separate destroyed CS. The wet-based method has numerous disadvantages-for instance, trace elements of CFA are dissolved in the medium, which can leach toxic heavy metals that are fatal for living beings [21]. Land and water are the basic requirements of this process which is not economical. Due to the presence of high calcium content in CS, it has restricted uses in cement or in cement additives. In this process, the recovered CS are wet and must be dried, which is an energy-intensive process, and hence, expensive.

Kiani et al., 2016, used a unique and innovative novel system to extract CS from CFA by the inverted reflux classifier (IRC), covering single and multistage processing. The system consists of a series of parallel inclined channels mounted underneath an inverted liquid fluidized bed. This particular technique reported high recovery of CS, due to the so-called Boycott effect, which arises in inclined settling. The purity of the recovered CS was about $17 \%$ by volume, and recovery was $70 \%$. However, by using all the three stages, the recovery fell to $50 \%$ and concluded that accelerated separation of the positively buoyant CS is promoted by the presence of a high concentration of the negatively buoyant CFA, and therefore, a single separation stage is preferable [21].

\subsection{Dry Separation Method for Recovery of Cenospheres from CFA}

The dry separation method is an alternative to the wet separation method, and has several advantages when recovering CS and other CFA particles [21]. For instance, in the dry-based method, particles are not subjected to liquid media, no chemicals (such as acetone) are involved, and there are no chemical reactions, and hence, no water pollution. Secondly, because there is no liquid media, the chemical composition of particles remains unchanged. Thirdly, since the particles are recovered in dry form, no drying process is required as in the case of the wet method. Thus, it is more economical because less electricity and space is needed [21].

For the separation of CS from CFA most widely used instrument is air classifiers. These types of instruments separate the particles are based on their geometry or aerodynamic equivalent diameter and density [63]. The separation of cenospheres from CFA by air classifiers relies on the airstream being applied in the air classifiers from the bottom. When this happens, the particles are subjected to gravity, and drag forces then in the direction opposite to the airstream applied. Thus, the heavier particles, whose terminal settling 
velocity is more than the velocity of the applied air in an airstream, then, the particles will settle down against the airstream. While, on the other hand, in the case of lighter particles, whose terminal velocity is less than the applied air velocity, then the particles will move towards the air stream and finally will reach the top of the air classifiers [55].

Hirajima et al., 2010, recovered the CFA CS, and estimated the magnitude of separation for both wet and dry separation methods by applying the terminal velocity concept of particles. The diameter of the particles and density was used to calculate terminal velocity for separation efficiency of both dry and wet methods. The outcomes of this approach were confirmed by using a micron separator. The recovery of the cenospheres was only $4 \%$ lower than the estimated value (70\%). By using a micro separator, recovery efficiency reached to $66 \%$ - which was almost equivalent to the estimated value of $70 \%$. Furthermore, a group of investigators used micron separators to study the efficiency of the dry separation method for extracting CS from CFA [51].

Petrus et al., 2011, recovered CFA CS through employing a dry separation method that used closed-type pneumatic separator. The feed rate was maintained by keeping $20 \%$ CS in CFA. They also studied the particle size distribution of the recovered particles by using an LA-950 laser-scattering particle size distribution analyzer [57].

Wrona et al., 2020 [21], reported a novel dry separation method for the recovery of CS from CFA generated in Poland thermal power plants. The dry separation method is comprised of three sequential arrangements of techniques, in the following order: Firstly fluidized bed separation; secondly, screening; and finally, pneumatic separation. The first arrangement was associated with a mechanical activator to inhibit the agglomeration, and consequently, this step reduced the further processing of about $52-55 \%$ fractions of the cenospheric material by wt.\%. Furthermore, the obtained fractions were individually transferred to another section, i.e., pneumatic separation. It was found that the CFA have initially 0.64 wt.\% of CS of the total weight of CFA, i.e., CS concentrate that constituted about 17 wt.\% of the initial fly ash. By applying this novel technique, the CS recovery efficiency reached up to $81 \%$. Among all the raw materials present in CFA, almost $83 \%$ could be recovered by this dry novel separation method. The recovered CS could be further either purified or may be directly used in the various industries [21].

Some investigators have also used a triboelectric separation system to extract CS from CFA. Kiani et al., 2016, acomplished this by using an inverted reflux classifier (IRC), covering single and multistage processing. The system consisted of a series of parallel inclined channels mounted underneath an inverted liquid fluidized bed. This particular technique reported high recovery of CS, due to the so-called Boycott effect, which arises in inclined settling. The purity of the recovered CS was about $17 \%$ by volume, and recovery was $70 \%$. However, by using all the three stages, the recovery fell to $50 \%$. They concluded that accelerated separation of the positively buoyant CS is promoted by the presence of a high concentration of the negatively buoyant CFA, and therefore, a single separation stage is preferable [21,59].

\section{Applications of Cenospheres in Ceramics and Environmental Cleanup}

CS finds applications in all the fields which include building/construction materials [64], ceramics [65], plastics [28], construction [10], lightweight construction material [66], recreation [67], coating [31], automotive [28], paints and coatings [68], energy storage devices [69,70], polymer fillers [71], buoyancy and as low dielectric constant substrates [14]. They are best fitted for adding into silicone rubber to increase the conductivity. Besides this, it also increases rubbers' suitability as an electromagnetic wave absorbing material [71,72], which can be used in electronic, as a broad band microwave absorber, and radar-based applications [73]. 


\subsection{Applications of Cenospheres in Environmental Cleanup}

Due to its unique and remarkable features, it is widely used in environmental cleanup and building materials. Among environmental cleanup, it is used as a water purifying agent which helps to remove an excess of fluorides [74]. Until now, CFA have mainly been used for the adsorption of pollutants, such as dye, heavy metals, pesticides, etc., from wastewater. CFA as an adsorbent draws huge attention, due to their low cost, as mainly considered waste, have various structural materials like carbon, plerospheres, ferrospheres, and CS. Besides this, CFA have pores on their surface, which enhances the adsorption phenomenon. Thus, the adsorption is based on CFA is quite economical as the overall cost of remediation decreases drastically. There are few reports where, instead of whole CFA, their different structural particles have been used for wastewater treatment. For instance, CS are used after functionalization to remove specific organic or inorganic pollutants from wastewater [75]. However, the separation process of CS from CFA may increase the cost of the process, so it is less preferred. There are few instances where CFA and cenospheres have used as an adsorbent for air pollutant [22]. Moreover, there are several reports in the literature where cenospheres, extracted from CFA, were used for wastewater treatment. Markendya et al., 2014, utilized modified CS to remove disperse blue (DB) and disperse orange (DO) dye by batch adsorption study. The former removed $78 \%$, while the latter removed $81 \%$ dyes from the $40 \mathrm{~g} / \mathrm{L}$ concentrated aqueous solutions [50]. Markandeya et al., 2021, synthesized zeolites from CFA cenospheres and applied them for the remediation of disperse orange and disperse blue dyes from the textile mill effluent. The removal percentage of disperse orange (DO) was $96 \%$ under $119 \mathrm{~min}$, while for disperse blue (DB), it was $95.23 \%$ under $122 \mathrm{~min}$. The other parameters were almost similar for both the dyes. Finally, they concluded that the CS-derived zeolites are not only eco-friendly and economical; rather, they have the potential to remediate both DO and DB dye from the textile mill effluent [76].

Some investigators have also reported using these cenospheric particles after surface modification for the purification of wastewater. One investigation, led by Xu et al., 2011, showed the results of loading CS with magnesia, produced by a wet impregnation process with $\mathrm{MgCl}_{2}$ [74]. CS can be used for the solidification and removal of liquid and other hazardous wastes, along with the production of porous crystalline molded glass [30].

\subsection{Applications of Cenospheres in Construction}

Several investigators have reported the applications of CFA CS in civil engineering and construction, due to their unique and remarkable properties [66]. As a construction material, these CFA CS are used as a refractory material [77] because of their low TC and high-temperature resistance as these are formed by aluminosilicates phases which are thermally stable [25].

\subsubsection{Applications of Cenospheres for Concrete and Concrete with Lightweight Material}

In the field of construction materials, CFA cenospheres display a significant reduction in concrete density, while retaining most of its mechanical strength [41]. Due to this property, CFA cenospheres have higher mechanical strength per unit weight of concrete, thus, CFA cenospheres are a suitable material for manufacturing lightweight concrete [78]. CS are micron-sized spherical particles, which act as mini ball-bearings in concrete mixture. Due to ball-bearing effect of CS [14], if added in the conventional concrete mixture, it will increase the workability by keeping CS dosage 1 and $5 \%$. The ultra-fineness property of CS could also enrich 'finishability' and 'trowelability' of concrete [79]. CS have a property to act as structural aggregates, and thus, have a positive impact on the strength and density of the concrete that results in better packing [80]. Because CS have good water absorption capacity, they are added to concrete, allowing it to be desirably dry (water in concrete leads to corrosion) and also decrease its density $[81,82]$. 
CS can be used as an additive material for lightweight cement with reduced water release [83]. Souza et al., 2019, used the CS for manufacturing lightweight, high tensile strength concrete. For this investigation, they collected cenosphere from a Brazilian power plant, which has a total cenospheric content was $0.2 \%$ and size was varying from 30 to $300 \mu \mathrm{m}$. Concrete was manufactured by substituting 33,67 , and $100 \%$ FA by CFA extracted $\mathrm{CS}$, which exhibited higher strength than $70 \mathrm{MPa}$, while the density was just $1500 \mathrm{~kg} / \mathrm{m}^{-3}$. It was found that the addition of CS as FA drastically improved the specific strength of high-strength concrete by keeping the equivalent mechanical properties [84]. CS are widely used to manufacture lightweight concrete which are used as slate, shale, or expanded clay. Cenospheres are used to replace FA because CS density $\left(0.7 \mathrm{~g} / \mathrm{cm}^{3}\right)$ is lesser than water $\left(1 \mathrm{~g} / \mathrm{cm}^{3}\right)$, thus preparing lightweight concrete. The size of cenospheric particles varies, as per effective concrete mix. Less cement is required to cover the particles when using the remaining cement as lubrication to increase the workability. Due to the incorporation of CS in concrete, there is improved TC and could be used as a noise barrier. Due to the incorporation of CS, the compressive strength of the cement reduces, but this can be overcome by using silica nanoparticles [85]. Likov et al., 1999, manufactured lightweight hydrated products from the CFA CS. They concluded that on the increase of hardening temperature, there is enhanced crystallization of the hydrated products due to the CS and expensive additives [79]. Hanif et al., 2017 developed an ultra-lightweight cementitious composite by utilizing using aerogel and CS. Due to the utilization of both materials, there was a significant reduction in the density of the composite materials [86].

\subsubsection{Cenospheres as Replacement of Cement and Fine Aggregate (FA) from Concrete}

The CS extracted from CFA have similar properties to that of CFA, i.e., cementitious and pozzolanic properties, which makes them a suitable material for the replacement of cement in concrete [80]. Other properties, such as bulk density, particle size, and surface area, help to accelerate the hydration process of cement. CS have been widely used as a partial substitute material of FA, due to the similarity in the structure [87]. Due to the replacement of FA, by CS six major properties of the concrete were affected, i.e., (1) Thermal conductivity; (2) workability; (3) bulk density; (4) surface finish; (5) mechanical strength; (6) porosity. Few investigators said that even after the addition of CS in concrete by replacing FA, there was no major loss in the mechanical strength of concrete. However, consequently, the concrete pores volume was increased. This may adversely affect the permeability of concrete. Satpathy et al., 2019, said that to achieve desired mechanical features, there should be an optimum percentage of both CS and sintered CFA, i.e., $50 \%$ and $75 \%$, respectively [64]. Investigators replaced the FA with CS in 33, 67, and $100 \%$, and found that there is a gradual decrease in the compressive strength of the concrete. Moreover, it was also found that the addition of CS in any form in the concrete to replace FA, resulting in the adverse effect of hydration; hence, CS should be added only 5 to $10 \%$ [64]. Table 1 is showing the percentage removal of CS in the concrete by various investigators. 
Table 1. Percentage replacement by cenospheres in the concrete.

\begin{tabular}{|c|c|c|c|c|}
\hline S. No & \% Replacement & Density $\mathrm{Kg} / \mathrm{m}^{3}$ & W/C Ratio & Reference \\
\hline \multirow{4}{*}{1.} & 10 & 1724 & \multirow{4}{*}{0.32} & \multirow{4}{*}{ [88] } \\
\hline & 20 & 1592 & & \\
\hline & 30 & 1477 & & \\
\hline & 0 & 2200 & & \\
\hline \multirow{4}{*}{2.} & 40 & 1506 & \multirow{4}{*}{0.3} & \multirow{4}{*}{ [80] } \\
\hline & 50 & 1444 & & \\
\hline & 60 & 1342 & & \\
\hline & 70 & 1260 & & \\
\hline \multirow{3}{*}{3.} & 10 & 1900 & \multirow{3}{*}{0.3} & \multirow{3}{*}{ [86] } \\
\hline & 20 & 1700 & & \\
\hline & $\begin{array}{c}30 \\
5\end{array}$ & 1500 & & \\
\hline \multirow{4}{*}{4.} & 50 & 1980 & \multirow{4}{*}{-} & \multirow{4}{*}[64]{} \\
\hline & 75 & 1867 & & \\
\hline & 100 & 1769 & & \\
\hline & 30 & 1612 & & \\
\hline \multirow{4}{*}{5.} & 33 & 2134 & \multirow{4}{*}{0.2} & \multirow{4}{*}{ [84] } \\
\hline & 67 & 1912 & & \\
\hline & 100 & 1650 & & \\
\hline & 0 & 1870 & & \\
\hline \multirow{3}{*}{6.} & 50 & - & \multirow{3}{*}{-} & \multirow{3}{*}{ [43] } \\
\hline & 75 & - & & \\
\hline & 100 & - & & \\
\hline \multirow{2}{*}{7.} & 15 & & & \multirow{2}{*}{ [89] } \\
\hline & 20 & & & \\
\hline
\end{tabular}

\subsubsection{Cenospheres as an Insulating Material}

CS extracted from CFA have a large amount of mullite, so the CS are used as mullitecoated diesel engine components [9]., steel soaking, heat exchangers, industrial furnaces for glass re-melting, refractories, and aluminum reclamation [90]. The incorporation of CS as an additive in concrete provides them extra sound and heat insulation, due to their hollow spherical shape. Moreover, cenospheres also help in the insulation (sound and thermal) properties of plasters/coatings [91], and mortars used for buildings [86]. Adding 40\% cenosphere by volume to the cement matrix can increase the sound reduction coefficient by $100 \%$ [91]. The most recent applications of CS are in the field of energy storage, especially as a material for hydrogen storage [92]. Hanif et al., 2017, used aerogel and CFA extracted CS and developed a lightweight, composite material, which was also found to have excellent thermal insulation properties along with specific strength [86].

\subsubsection{Application of Cenospheres in Ceramics}

Qian et al. prepared porous mullite-based ceramics by gel casting method. This method procures mullite and extracts CS from the CFA [40]. The authors evaluated the impact of CS content and sintering on strength and density. The microstructure exhibited that CS could act as a sintering aid and a pore-forming agent. When the sintering temperature was high $\left(1200^{\circ} \mathrm{C}\right)$, then the obtained porous mullite ceramics was highly porous in nature, with low density and low thermal conductivity [40].

\subsubsection{Application of Cenospheres as Fillers and Nanofillers}

One of the major applications of cenospheres is as a cheap source of fillers. It is highly demanded in polymer and polymeric composite material, due to their high surface to volume ratio, which requires less binder, resin, and water to wet the surface. In the field of composites and nanocomposites, CS are used as lightweight fillers, due to their enhanced 
properties and reduced cost of the final product [93]. As a filler, they are also used in grout, due to their light color and fine size, which makes them suitable candidates for applications in filling pinholes. $\mathrm{CS}$ are rich in $\mathrm{Al}$ and $\mathrm{Si}$, which provide strength and hydration to binder agents. Packing of placed grouts has become much easier and effective, due to their perfectly spherical shape, scrubbing nature, and ability to roll in small holes. Danish et al., 2020, provided a detailed overview of the recovery and applications of CS extracted from CFA [14]. Krueger et al., 1966, utilized the CFA extracted CS for refractory purposes [77]. Some investigations concluded that using the CS as a nanofiller increased the porosity because of their spherical nature [94].

\subsubsection{Cenospheres as an Internal Curing Agent}

CS are porous in nature which is decided by the shell thickness, which is further governed by the alumina and silica content in the CFA. In order to become porous CS, there should be an optimum amount of alumina (directly) and silica (indirectly), which are associated with the shell's porosity and thickness [25]. CFA and CS have a high percentage of glass content, which could be eliminated by etching that will expose more pores on the surface of microspheres [95]. Due to this etching, the water holding capacity of the CS increases up to $180 \%$, which releases the water very gradually from the cement mixture to reduce autogenously shrinkage of concrete [17]. This internal curing can increase the compressive strength of cement concrete/mortars [96]. Liu et al. also prepared foam concrete from the CFA CS [58].

One of the important draws back of the addition of CS to cement mortar for plaster is that it increases the porosity, which may increase the seepage. From the analysis, the author found that, initially, the strength of the cement paste increased after the addition of CS, but over time, strength decreased [80]. Due to the addition of CS, the increased pozzolanic activity plays an important role in the reduction of strength over the period. They have reported that $10 \%$ replacement of CS by weight is an optimum replacement of FAC, which resulted in the increase in the porosity, due to the addition of CS. The higher percentage of CS in the mix adversely affected the durability of the concrete. Wang et al., 2017, revealed the internal curing of high-performing concrete composed of CS. They created pores on the surface of CS by chemical etching, and found that the perforated CS water absorption capacity was $180 \%$, and the loaded water could be easily released from CS under higher relative humidity $(85 \%)$. Due to this internal curing, there was no autogenous shrinkage of the mortar; there was also high compressive strength of the cement mortar [97].

\subsubsection{Application of Cenospheres in Manufacturing of Composite Material}

As the CS are lightweight and high strength material, they are considered as a widely suitable material for the designing of modern lightweight composite materials that have high demand in the automotive and aerospace industry [98-100].

In the field of polymers, copper-coated CS and their incorporation in organic polymers, opens a new possibility to change the electric properties of polymers from an insulator to a conductive material [46]. CS can be coated or covered by various metals and act as a magnetic waves shield; therefore, it can be used in electronic and radar applications. Bora et al., 2016 and 2018, used the CS extracted from CFA, to prepare composite material, which was used as microwave absorber [73]; while, in another approach, polyaniline-cobalt coated the cenosphere composite film was used for electromagnetic interference shielding [101]. Nickel-coated CS display a potential for protection and microwave absorption applications [102]. Zeng et al., 2006, extracted the CFA CS, and then coated it with $\mathrm{BaFe}_{12} \mathrm{O}_{19}$ using a sol gel process. The $\mathrm{BaFe}_{12} \mathrm{O}_{19}$ was synthesized by using $\mathrm{Fe}\left(\mathrm{NO}_{3}\right)_{3} \cdot 9 \mathrm{H} 2 \mathrm{O}, \mathrm{Ba}\left(\mathrm{NO}_{3}\right)_{2}$, and citric acid as precursor materials. Furthermore, they thoroughly studied the structural properties of the developed material. They concluded that because of the even and continual Ba hexaferrite coating, the nonconductive CS acquired the magnetic properties [103]. Valdez et al., 2011, used the CFA extracted CS as an ultra-low-TC coating on the barriers. They used different temperatures to sinter CS. Low TC was observed with the nonsintered 
one due to the presence of hollow air spaces in the CS, while sintering slightly boosted the heat conductivity due to the change in microstructures [49].

Irtiseva et al., 2021, developed a composite material, composed of recycled rubber, CS, and biobinder. Three such phase composites were prepared in two forms, i.e., block and granules, where the former was used to investigate mechanical features and density, while the latter form was used for absorption of oil and water products. The maximum compressive strength was when there was no CS and rubber was added, which was $79.3 \mathrm{MPa}$ [71]. CS coated with nanosilica can be used to produce superhydrophobic surfaces [104]. The several composite materials that use CS very frequently are: Polyurethane composites, syntactic polymer foam, functionally gradient materials, high impact strength nylon composites, and polyester composites [105], as depicted in Figure 1. CS are widely used to manufacture several composite and nanocomposite materials that are favored by the cenosphere's particle size, spherical shape, inertness, etc. This investigation found that the sample contains a hollow structure with a magnetic property [106]. Tiwari and Bose, 2004, observed the effect that adding CS has on the acoustic properties of concrete. They said that the acoustic properties of concrete increased significantly with the reduction in the density of the concrete [91]. Cardoso and Shukla 2002, reported that due to the addition of CS in the concrete, its fracture toughness increased by $200 \%$ [107]. CS is being used as a filler in many polymer composites, due to its unique properties. Cenosphere can be coated with copper to manufacture conducting polymers to be used for electromagnetic shielding applications [108]. Some of the investigators have also reported that it is possible to manufacture LWHS material of polyester by controllable size and altered polyester [107] By utilizing CS in polyethylene (high density), different colors could be obtained, which will simultaneously reduce the requirement of pigment [28].

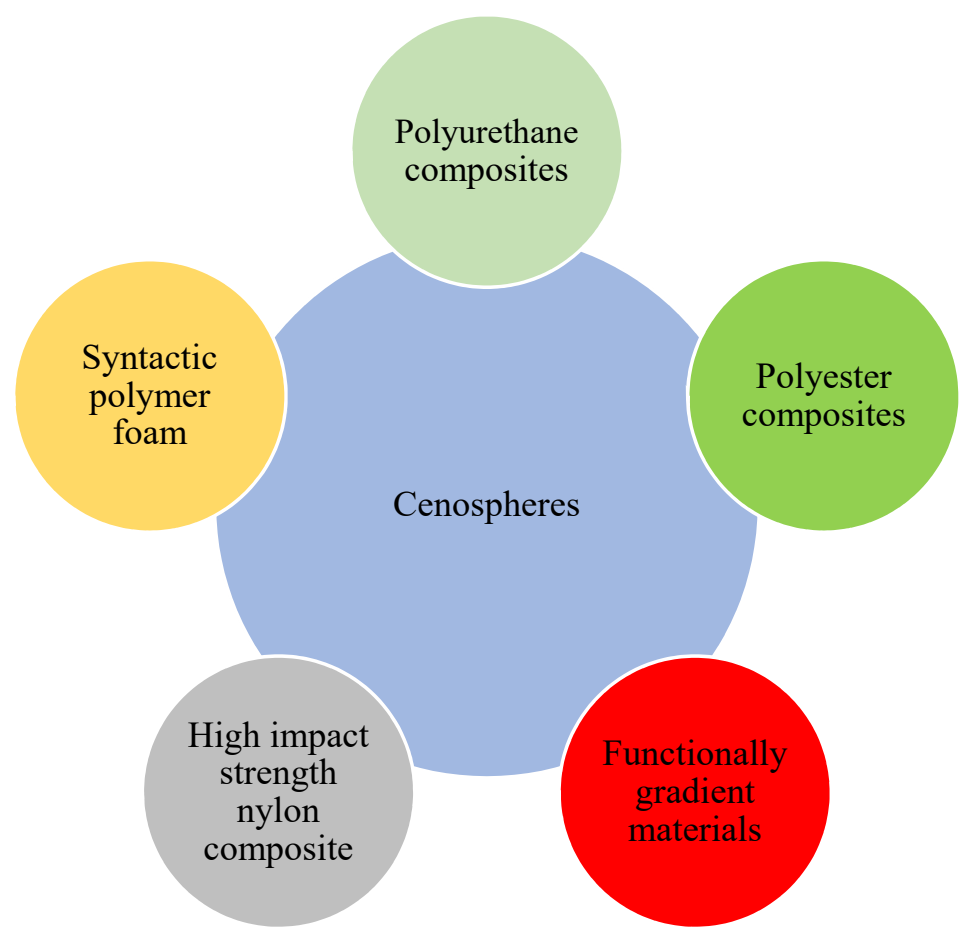

Figure 1. Applications of cenospheres as a filler in composites and nanocomposites.

\subsection{Applications of Cenospheres in Syntactic Foams and Spheroplastics}

Foams that are composed of CS are low weight-high strength [72], high resistance to gas erosion, can be cast in the desired shape, which make these foams desirable material in preparing high-performance products, such as heat insulators, thermal resistors, etc. [109]. CS-based ceramic insulation material was manufactured for reusable ceramic heat insulators for the space shuttle, which can protect the basic structure of the vehicle [30]. These 
foams are manufactured by mixing matrix material and CS to obtain several beneficial properties like less moisture absorption, good buoyancy, high strength, high damage resistance, and energy absorption [110]. Due to all these unique properties of cenospheric foams, it is widely used in marine, aerospace, and automotive industries for developing materials that can take high hydrostatic loads [110].

One of the most emerging applications of CFA extracted CS in ceramics is their application as fillers in spheroplastics. Lisyatnikov et al., 2020, reported the production of spheroplastics with high dielectric current from the waste CFA on a solid fuel [111]. The only major problem is the presence of toxic heavy metals $(\mathrm{Hg}, \mathrm{Cu}, \mathrm{Cr}, \mathrm{Cd}, \mathrm{Ni}, \mathrm{As}, \mathrm{Pb}$, $\mathrm{Zn}$, etc.) along with the CS. Besides these heavy metals, some of the investigators have also reported the presence of few radioactive elements, which may have further negative impacts on the material, as well as the handlers.

\subsection{Miscellaneous Applications of Cenospheres}

CS are applied in several applications-for instance, phase change material, etc. Menenzes et al., 2016, studied the TC of CS, extracted from CFA, which was experimentally determined for particle diameter size ranges of $<105 \mu \mathrm{m}, 105 \mu \mathrm{m}$ to $180 \mu \mathrm{m}$, and $>180 \mu \mathrm{m}$ using concentric spheres method [112]. Besides this, there are several reports where investigators have mentioned the applications of CFA CS paints and enamels. These CS acted as a reinforcement for the matrix of the polymer composites that can be added to the paints [113]. It has also been used in fluidized bed material [114], as reported by Berkowicz et al., 2016. Some of the researchers have used CS in the petroleum industry, for several purposes while digging wells. Moreover, some of them used CS as an additive in drilling mud, which not only helps in the drilling process but also increases the life span of the drilling equipment. It has also been used to prepare well cements that fill the space between the casting and well boundary-either to protect from groundwater or separate different wells. Well cements, prepared using CS, were not only lightweight, but also economical —which was bestowed with high strength and heat insulation properties [71]. Several investigators have also reported the application of CS in the pharmaceutical industry, as a carrier molecule for drugs, as well as in radiodiagonosis and cancer treatment $[115,116]$ There is also the possibility of applications of modified CS airplane parts, defense components, due to their high mechanical strength. Table 2 shows the summarized applications of CS in various applications.

Table 2. Research that carried out in different fields incorporating cenospheres.

\begin{tabular}{|c|c|c|c|}
\hline S. No. & Topic & Use/Study Outcomes & References \\
\hline 1. & $\begin{array}{l}\text { Application in } \\
\text { cementitious materials }\end{array}$ & $\begin{array}{l}\text { Production of lightweight material. } \\
\text { Improvisation of thermal and acoustic properties of } \\
\text { cementitious materials. }\end{array}$ & {$[31]$} \\
\hline 2. & $\begin{array}{l}\text { Effect on mechanical } \\
\text { properties of } \\
\text { cement-based } \\
\text { composites }\end{array}$ & Reduced the shrinkage of cement-based composites. & [117] \\
\hline 3. & $\begin{array}{l}\text { Alkali activated } \\
\text { cenosphere as a binder } \\
\text { for preparation of } \\
\text { lightweight } \\
\text { hemp-concrete }\end{array}$ & $\begin{array}{c}\text { Provides compressive strength by using less energy. } \\
\text { An alternative sustainable binder because of its lower } \\
\text { carbon emissions without compromising on } \\
\text { mechanical properties. }\end{array}$ & {$[118]$} \\
\hline 4. & $\begin{array}{l}\text { Cenosphere for } \\
\text { designing } \\
\text { synthetic foams }\end{array}$ & $\begin{array}{l}\text { Increases strength. } \\
\text { Improves insulation capacity. } \\
\text { Lightweight. }\end{array}$ & {$[119]$} \\
\hline 5. & $\begin{array}{l}\text { Hydroxyapatite } \\
\text { cenosphere for water } \\
\text { treatment }\end{array}$ & $\begin{array}{l}\text { Effective for treating heavy metals (lead and copper) } \\
\text { contaminated water. }\end{array}$ & [120] \\
\hline
\end{tabular}


Table 2. Cont.

\begin{tabular}{|c|c|c|c|}
\hline S. No. & Topic & Use/Study Outcomes & References \\
\hline 6. & $\begin{array}{l}\mathrm{CS} \text { for making long-lasting } \\
\text { anode materials for batteries }\end{array}$ & $\begin{array}{l}\text { Improves cycling stability. } \\
\text { Increases rate capability and service life Improves } \\
\text { safety }\end{array}$ & [121] \\
\hline 7. & $\begin{array}{l}\text { CFA CS for the formation of } \\
\text { lightweight concrete (LWC) }\end{array}$ & $\begin{array}{l}\text { Increased cenosphere content decreases the density } \\
\text { of concrete. } \\
\text { Perfect for development of structural LWC. }\end{array}$ & [64] \\
\hline 8. & $\begin{array}{l}\text { Cenosphere as fillers for } \\
\text { flexural fatigue properties of } \\
\text { thin cementitious materials }\end{array}$ & Improves strength and ductility and flexural fatigue & [122] \\
\hline 9. & $\begin{array}{l}\text { Glass CS for development of } \\
\text { lightweight cementitious } \\
\text { composites }\end{array}$ & $\begin{array}{l}\text { Outstanding in cementitious composites formation. } \\
\text { Highly compatible with reinforced fiber matrix. } \\
\text { Helps to improve the thermal insulation. }\end{array}$ & [123] \\
\hline 10. & $\begin{array}{l}\text { Synthesis of nano-Ni coated } \\
\text { CScomposites }\end{array}$ & $\begin{array}{c}\text { Ease in processing. } \\
\text { Lightweight. } \\
\text { Cost-effective. } \\
\text { Can be used in electromagnetic shielding. }\end{array}$ & [124] \\
\hline 11. & $\begin{array}{l}\text { CS for lightweight } \\
\text { ferrocement (green) } \\
\text { formation }\end{array}$ & $\begin{array}{l}\text { Increases compressive strength, ductility, and } \\
\text { flexural strength. Improves durability. }\end{array}$ & [125] \\
\hline 12. & $\begin{array}{l}\text { CS as filler in cement-based } \\
\text { composites }\end{array}$ & $\begin{array}{c}\text { Increases strength. } \\
\text { Used in casting lightweight load-carrying structural } \\
\text { members. }\end{array}$ & [126] \\
\hline 13. & $\begin{array}{l}\text { Cenosphere's stability } \\
\text { against alkali-silica reaction } \\
\text { in cement composite }\end{array}$ & $\begin{array}{l}\text { Protection from the alkali-silica reaction. } \\
\text { Show pozzolanic reactivity, which increases with } \\
\text { temperature. }\end{array}$ & [127] \\
\hline 14. & $\begin{array}{l}\text { Formation of cenosphere } \\
\text { concrete material }\end{array}$ & $\begin{array}{l}\text { Increases water uptake due to the porous nature } \\
\text { of CS. } \\
\text { Improves equilibrium water content. }\end{array}$ & [17] \\
\hline 15. & $\begin{array}{l}\text { CS as FA for development of } \\
\text { lightweight high strength } \\
\text { concrete }\end{array}$ & $\begin{array}{l}\text { Increases compressive strength. } \\
\text { Low porosity. } \\
\text { Low density. }\end{array}$ & [84] \\
\hline 16. & $\begin{array}{l}\text { Properties of asphalt } \\
\text { concrete and cenosphere } \\
\text { cement }\end{array}$ & $\begin{array}{l}\text { Increment of } 17 \% \text { in density of concrete by } \\
\text { replacing FA with CS. } \\
\text { Increment of } 40 \% \text { in sound absorption by using } \\
\text { cement with CS. }\end{array}$ & [91] \\
\hline 17. & $\begin{array}{l}\text { CS for preparation of } \\
\text { lightweight cementitious } \\
\text { material }\end{array}$ & $\begin{array}{l}\text { Improves mechanical properties. } \\
\text { Reduces permeability. } \\
\text { Increases durability. } \\
\text { Improves thermal insulation. }\end{array}$ & [86] \\
\hline 18. & $\begin{array}{l}\text { Cenosphere's use in } \\
\text { development of lightweight } \\
\text { concrete }\end{array}$ & Improves TC. & [128] \\
\hline 19. & $\begin{array}{l}\text { Cenosphere's use for } \\
\text { microencapsulating phase } \\
\text { change materials (PCM) in } \\
\text { concrete }\end{array}$ & $\begin{array}{l}\text { Cost-effective. } \\
\text { Increases thermal storage stability and capacity. } \\
\text { Improves mechanical properties. }\end{array}$ & [129] \\
\hline 20. & $\begin{array}{l}\text { CS for internal curing of } \\
\text { high-performance concrete }\end{array}$ & $\begin{array}{l}\text { Increases compressive strength. } \\
\text { Removes of autogenous shrinkage. } \\
\text { Reduces stress concentration. }\end{array}$ & [97] \\
\hline 21. & $\begin{array}{l}\text { Cenosphere's effect on } \\
\text { properties of CFA brick }\end{array}$ & $\begin{array}{l}\text { Reduces in bulk density. } \\
\text { Improves performance on cold region. } \\
\text { Improves insulating properties. } \\
\text { Financially sound. }\end{array}$ & [130] \\
\hline 22. & CS: Use in refractories & $\begin{array}{l}\text { CS were used as feedstock to form innovative } \\
\text { refractories. } \\
\text { Cenosphere incorporation helped to meet enhanced } \\
\text { performance characteristics. }\end{array}$ & [77] \\
\hline
\end{tabular}




\section{Conclusions}

CFA is considered hazardous waste, due to the presence of numerous heavy metals. However, it has been categorized into useable materials in the last decade, due to their minerals and structurally important structures, such as cenospheres, plerospheres, and ferrospheres. Cenospheres possess unique and remarkable physical, chemical, and mechanical properties; thus, it has drawn the attention of the scientist from all parts of the world in ceramics, environmental cleanup, and lightweight materials. Cenospheres could be either magnetic or nonmagnetic, based on the Fe content. The cenospheres could be recovered from CFA by both dry and wet-based methods, but the wet-based method is preferred because of their economical nature [59]. The efficient recovery of cenospheres was least affected by the morphological properties of the cenospheres. To date, cenospheres are successfully used in the field of ceramics, wastewater treatment, agriculture, and electronics, and soon they will be considered a material of the future.

Author Contributions: Conceptualization, G.G., V.K.Y., A.J.; Data curation, N.C., C.T.S., S.I. and A.J., methodology, N.G., G.G., N.C., C.T.S. and V.T.; validation, K.K.Y., S.I., N.C., B.-H.J. and A.J.; formal analysis, V.K.Y., N.C., N.G., G.G. and C.T.S.; resources, V.T., K.K.Y., S.I., N.C., B.-H.J. and C.T.S.; writing-original draft preparation, V.K.Y., N.C.; writing-review and editing, V.K.Y., V.T., G.G., A.J. and C.T.S.; supervision, V.K.Y., N.G., S.I. and B.-H.J.; project administration V.K.Y., V.T., K.K.Y., S.I. and C.T.S.; Funding acquisition, B.-H.J., S.I., V.T. and K.K.Y.; Software's, A.J., K.K.Y., G.G., N.G. and B.-H.J.; Visualization, V.T., V.K.Y. and B.-H.J. All authors have read and agreed to the published version of the manuscript.

Funding: The authors gratefully acknowledge the Deanship of Scientific Research, King Khalid University (KKU), Abha-Asir, Kingdom of Saudi Arabia for funding this research work under the grant number RGP.1/74/42.

Data Availability Statement: Not applicable.

Conflicts of Interest: The authors declare no conflict of interest.

\section{Abbreviations}

$\begin{array}{ll}\text { CS } & \text { Cenospheres } \\ \text { TC } & \text { Thermal conductivity } \\ \text { CFA } & \text { Coal fly ash } \\ \text { TPPs } & \text { Thermal power plants } \\ \text { LWC } & \text { Lightweight concrete }\end{array}$

\section{References}

1. Yadav, V.K.; Gnanamoorthy, G.; Cabral-Pinto, M.M.S.; Alam, J.; Ahamed, M.; Gupta, N.; Singh, B.; Choudhary, N.; Inwati, G.K.; Yadav, K.K. Variations and similarities in structural, chemical, and elemental properties on the ashes derived from the coal due to their combustion in open and controlled manner. Environ. Sci. Pollut. Res. 2021, 28, 32609-32625. [CrossRef]

2. Yadav, V.K.; Fulekar, M.H. Advances in Methods for Recovery of Ferrous, Alumina, and Silica Nanoparticles from Fly Ash Waste. Ceramics 2020, 3, 384-420. [CrossRef]

3. Naveen Kumar, B.; Radhika, R.; Kumar, V.V.; Chakradhar, B. Regulatory Requirements for Fly ash Utilisation from Thermal Power Plants in India. Int. J. Appl. Environ. Sci. 2020, 15, 151-166.

4. Virendra, K.Y.; Pallavi, S.; Chagan, L.; Govindhan, G.; Nisha, C.; Bijendra, S.; Neha, T.; Haresh, K.; Pankaj, K. Synthesis and Characterization of Mullites From Silicoaluminous Fly Ash Waste. Int. J. Appl. Nanotechnol. Res. IJANR 2020, 5, 10-25. [CrossRef]

5. Dzikuć, M.; Kuryło, P.; Dudziak, R.; Szufa, S.; Dzikuć, M.; Godzisz, K. Selected Aspects of Combustion Optimization of Coal in Power Plants. Energies 2020, 13, 2208. [CrossRef]

6. Nisha, C.; Virendra Kumar, Y.; Parth, M.; Samreen Heena, K.; Gajendra Kumar, I.; Suriyaprabha, R.; Bijendra, S.; Yadav, A.K.; Raman Kumar, R. Recovery of Natural Nanostructured Minerals: Ferrospheres, Plerospheres, Cenospheres, and Carbonaceous Particles From Fly Ash. In Handbook of Research on Emerging Developments and Environmental Impacts of Ecological Chemistry; Gheorghe, D., Ashok, V., Eds.; IGI Global: Hershey, PA, USA, 2020; pp. 450-470. [CrossRef]

7. Goodarzi, F.; Sanei, H. Plerosphere and its role in reduction of emitted fine fly ash particles from pulverized coal-fired power plants. Fuel 2009, 88, 382-386. [CrossRef]

8. Strzałkowska, E. Morphology, chemical and mineralogical composition of magnetic fraction of coal fly ash. Int. J. Coal Geol. 2021, 240, 103746. [CrossRef] 
9. Ranjbar, N.; Künzel, C. Cenospheres: A review. Fuel 2017, 207, 1-12. [CrossRef]

10. Ngu, L.-N.; Wu, H.; Zhang, D.-K. Characterization of Ash Cenospheres in Fly Ash from Australian Power Stations. Energy Fuels 2007, 21, 3437-3445. [CrossRef]

11. Gupta, S.; Chaudhary, S. 21-Use of fly ash for the development of sustainable construction materials. In New Materials in Civil Engineering; Samui, P., Kim, D., Iyer, N.R., Chaudhary, S., Eds.; Butterworth-Heinemann: Oxford, UK, 2020 ; pp. 677-689. [CrossRef]

12. Soh, W.M.; Tan, J.; Heng, J.Y.Y.; Cheeseman, C. Production of Cenospheres from Coal Fly Ash through Vertical Thermal Flame (VTF) Process. Mater. Sci. Forum 2017, 880, 7-10. [CrossRef]

13. Strzałkowska, E.; Adamczyk, Z. Influence of chemical composition of fly-ash cenospheres on their grains size. Int. J. Environ. Sci. Technol. 2020, 17, 809-818. [CrossRef]

14. Danish, A.; Mosaberpanah, M.A. Formation mechanism and applications of cenospheres: A review. J. Mater. Sci. 2020, 55, 4539-4557. [CrossRef]

15. Yoriya, S.; Intana, T.; Tepsri, P. Separation of Cenospheres from Lignite Fly Ash Using Acetone-Water Mixture. Appl. Sci. 2019, 9, 3792. [CrossRef]

16. Żyrkowski, M.; Neto, R.C.; Santos, L.F.; Witkowski, K. Characterization of fly-ash cenospheres from coal-fired power plant unit. Fuel 2016, 174, 49-53. [CrossRef]

17. Shukla, A.; Bose, A. Uptake and loss of water in a cenosphere-concrete composite material. Cem. Concr. Res. 2003, 33, 1681-1686. [CrossRef]

18. Li, Y.; Wu, H. Ash Cenosphere from Solid Fuels Combustion. Part 1: An Investigation into Its Formation Mechanism Using Pyrite as a Model Fuel. Energy Fuels 2012, 26, 130-137. [CrossRef]

19. Chen, Z.; Li, J.; Yang, E.-H. Development of Ultra-Lightweight and High Strength Engineered Cementitious Composites. J. Compos. Sci. 2021, 5, 113. [CrossRef]

20. Li, Y. Ash Cenosphere Formation, Fragmentation and its Contribution to Particulate Matter Emission during Solid Fuels Combustion. Ph.D. Thesis, Curtin University, Curtin, Australia, 2012.

21. Wrona, J.; Żukowski, W.; Bradło, D.; Czupryński, P. Recovery of Cenospheres and Fine Fraction from Coal Fly Ash by a Novel Dry Separation Method. Energies 2020, 13, 3576. [CrossRef]

22. Ge, J.C.; Yoon, S.K.; Choi, N.J. Application of Fly Ash as an Adsorbent for Removal of Air and Water Pollutants. Appl. Sci. 2018, 8, 1116. [CrossRef]

23. Kleinhans, U.; Wieland, C.; Frandsen, F.J.; Spliethoff, H. Ash formation and deposition in coal and biomass fired combustion systems: Progress and challenges in the field of ash particle sticking and rebound behavior. Prog. Energy Combust. Sci. 2018, 68, 65-168. [CrossRef]

24. Yoriya, S.; Tepsri, P. Separation Process and Microstructure-Chemical Composition Relationship of Cenospheres from Lignite Fly Ash Produced from Coal-Fired Power Plant in Thailand. Appl. Sci. 2020, 10, 5512. [CrossRef]

25. Fomenko, E.; Anshits, N.; Solovyov, L.; Mikhaylova, O.; Anshits, A. Composition and Morphology of Fly Ash Cenospheres Produced from the Combustion of Kuznetsk Coal. Energy Fuels 2013, 27, 5440-5448. [CrossRef]

26. Fomenko, E.; Anshits, N.; Solov'ev, L.; Mikhailova, O.; Anshits, A. Composition and structure of the shells of fly ash cenospheres from the combustion of coal of the Kuznetsk Basin. Solid Fuel Chem. 2014, 48, 129-139. [CrossRef]

27. Fomenko, E.V.; Rogovenko, E.S.; Solovyov, L.A.; Anshits, A.G. Gas permeation properties of hollow glass-crystalline microspheres. RSC Adv. 2014, 4, 9997-10000. [CrossRef]

28. Nakonieczny, D.; Antonowicz, M.; Paszenda, Z. Cenospheres and their application advantages in biomedical engineering-A systematic review. Rev. Adv. Mater. Sci. 2020, 59, 115-130. [CrossRef]

29. Drozhzhin, V.S.; Shpirt, M.Y.; Danilin, L.D.; Kuvaev, M.D.; Pikulin, I.V.; Potemkin, G.A.; Redyushev, S.A. Formation processes and main properties of hollow aluminosilicate microspheres in fly ash from thermal power stations. Solid Fuel Chem. 2008, 42, 107-119. [CrossRef]

30. Anshits, N.; Vereshchagina, T.; Fomenko, E.; Kruchek, D.M.; Bayukov, O.; Kyrenskii, L.V.; Zykova, I.; Paretskov, E.N.; Anshits, A.G. Coal fly ash cenospheres and their application for immobilization of liquid radioactive waste. In Proceedings of the 10th International Conference on Environmental Remediation and Radioactive Waste Management, ICEM'05, Glasgow, Scotland, 3-8 September 2005; American Society of Mechanical Engineers: New York, NY, USA, 2005; Volume 2005, pp. 1124-1131.

31. Adesina, A. Sustainable application of cenospheres in cementitious materials-Overview of performance. Dev. Built Environ. 2020, 4, 100029. [CrossRef]

32. Jiang, T.; Gao, Y.; Wang, Y.; Zhao, Z.; Yu, J.; Yang, K.; Zhao, Y.; Li, W.; Wu, X. Development and Mechanical Characterization of HGMS-EHS-Reinforced Hollow Glass Bead Composites. ACS Omega 2020, 5, 6725-6737. [CrossRef] [PubMed]

33. Shao, Y.; Jia, D.; Liu, B. Characterization of porous silicon nitride ceramics by pressureless sintering using fly ash cenosphere as a pore-forming agent. J. Eur. Ceram. Soc. 2009, 29, 1529-1534. [CrossRef]

34. Leelarungroj, K.; Likitlersuang, S.; Chompoorat, T.; Janjaroen, D. Leaching mechanisms of heavy metals from fly ash stabilised soils. Waste Manag. Res. 2018, 36, 616-623. [CrossRef] [PubMed]

35. Sandeep, P.; Sahu, S.K.; Kothai, P.; Pandit, G.G. Leaching Behavior of Selected Trace and Toxic Metals in Coal Fly Ash Samples Collected from Two Thermal Power Plants, India. Bull. Environ. Contam. Toxicol. 2016, 97, 425-431. [CrossRef] [PubMed] 
36. Vassilev, S.V.; Menendez, R.; Diaz-Somoano, M.; Martinez-Tarazona, M.R. Phase-mineral and chemical composition of coal fly ashes as a basis for their multicomponent utilization. 2. Characterization of ceramic cenosphere and salt concentrates. Fuel 2004, 83, 585-603. [CrossRef]

37. Li, Y.; Gao, X.; Wu, H. Further Investigation into the Formation Mechanism of Ash Cenospheres from an Australian Coal-Fired Power Station. Energy Fuels 2013, 27, 811-815. [CrossRef]

38. Jiang, L.; Elbaz, A.M.; Guida, P.; Al-Noman, S.M.; AlGhamdi, I.A.; Saxena, S.; Roberts, W.L. Cenosphere Formation during Single-Droplet Combustion of Heavy Fuel Oil. Energy Fuels 2019, 33, 1570-1581. [CrossRef]

39. Urunkar, Y.; Pandit, A.; Bhargava, P.; Joshi, J.; Mathpati, C.; Vasanthakumaran, S.; Jain, D.; Hussain, Z.; Patel, S.; More, V. Light-weight thermal insulating fly ash cenosphere ceramics. Int. J. Appl. Ceram. Technol. 2018, 15, 1467-1477. [CrossRef]

40. Qian, H.; Cheng, X.; Zhang, H.; Zhang, R.; Wang, Y. Preparation of Porous Mullite Ceramics Using Fly Ash Cenosphere as a Pore-Forming Agent by Gelcasting Process. Int. J. Appl. Ceram. Technol. 2014, 11, 858-863. [CrossRef]

41. Haustein, E.; Kuryłowicz-Cudowska, A. The Effect of Fly Ash Microspheres on the Pore Structure of Concrete. Minerals 2020, 10, 58. [CrossRef]

42. Biju-Duval, P. A New Porous Material Based on Cenospheres. Master's Thesis, Georgia Institute of Technology, Atlanta, GA, USA, 2007.

43. Patel, S.K.; Majhi, R.K.; Satpathy, H.P.; Nayak, A.N. Durability and microstructural properties of lightweight concrete manufactured with fly ash cenosphere and sintered fly ash aggregate. Constr. Build. Mater. 2019, 226, 579-590. [CrossRef]

44. Chávez-Valdez, A.; Vargas-Gutiérrez, G.; Almanza-Robles, J.M.; Arizmendi-Morquecho, A. Fly Ash Cenospheres Coatings by EPD-Microwave Sintering Process for SiC Corrosion Resistance. Key Eng. Mater. 2009, 412, 201-206. [CrossRef]

45. Kumar, P.; Maiti, U.; Sikdar, A.; Das, T.; Kumar, A.; Sudarsan, V. Recent Advances in Polymer and Polymer Composites for Electromagnetic Interference Shielding: Review and Future Prospects. Polym. Rev. 2019, 59, 687-738. [CrossRef]

46. Singh, A.K.; Shishkin, A.; Koppel, T.; Gupta, N. A review of porous lightweight composite materials for electromagnetic interference shielding. Compos. Part B Eng. 2018, 149, 188-197. [CrossRef]

47. Bora, P.J.; Mallik, N.; Ramamurthy, P.C.; Kishore; Madras, G. Poly(vinyl butyral) -polyaniline-magnetically functionalized fly ash cenosphere composite film for electromagnetic interference shielding. Compos. Part B Eng. 2016, 106, 224-233. [CrossRef]

48. Manocha, L.M.; Ram, K.A.; Manocha, S.M. Separation of Cenospheres from Fly Ashes by Floatation Method. Eurasian ChemTech J. 2011, 13, 89-95. [CrossRef]

49. Chávez-Valdez, A.; Arizmendi-Morquecho, A.; Vargas, G.; Almanza, J.M.; Alvarez-Quintana, J. Ultra-low thermal conductivity thermal barrier coatings from recycled fly-ash cenospheres. Acta Mater. 2011, 59, 2556-2562. [CrossRef]

50. Tiwari, M.; Shukla, S.P.; Mohan, D.; Bhargava, D.S.; Kisku, G.C. Modified Cenospheres as an Adsorbent for the Removal of Disperse Dyes. Adv. Environ. Chem. 2015, 2015, 349254. [CrossRef]

51. Hirajima, T.; Petrus, H.T.B.M.; Oosako, Y.; Nonaka, M.; Sasaki, K.; Ando, T. Recovery of cenospheres from coal fly ash using a dry separation process: Separation estimation and potential application. Int. J. Miner. Process. 2010, 95, 18-24. [CrossRef]

52. Beddu, S.; Zainoodin, M.; Basri, A.; Itam, Z.; Ahmadi, R.; Abd Manan, T.S. The potential of cenospheres production from Malaysian coal power plants. IOP Conf. Ser. Mater. Sci. Eng. 2021, 1101, 012012. [CrossRef]

53. Eisele, T.; Kawatra, S. Use of froth flotation to remove unburned carbon from fly ash. Miner. Process. Extr. Metall. Rev. 2002, 23, 1-10. [CrossRef]

54. Walker, A.; Wheelock, T.D. Separation of Carbon from Fly Ash Using Froth Flotation. Coal Prep. 2006, 26, 235-250. [CrossRef]

55. Saputra, F.Y.A.; Sutijan; Petrus, H.T.B.M. Cenosphere Separation from Fly Ash Using Modified Gravity Separator: Feed Ratio Assessment and Stream Velocity Optimization. IOP Conf. Ser. Mater. Sci. Eng. 2020, 742. [CrossRef]

56. Ramme, B.W.; Noegel, J.J.; Rohatgi, P.K. Separtion of Cenospheres from Fly Ash. U.S. Patent 8,520,210, 27 August 2013.

57. Petrus, H.T.B.M.; Hirajima, T.; Oosako, Y.; Nonaka, M.; Sasaki, K.; Ando, T. Performance of dry-separation processes in the recovery of cenospheres from fly ash and their implementation in a recovery unit. Int. J. Miner. Process. 2011, 98, 15-23. [CrossRef]

58. Liu, Z.; Zhao, K.; Tang, Y.; Hu, C. Preparation of a Cenosphere Curing Agent and Its Application to Foam Concrete. Adv. Mater. Sci. Eng. 2019, 2019, 7523492. [CrossRef]

59. Kiani, A.; Zhou, J.; Galvin, K. Multistage Concentration of Cenospheres in Fly Ash Using the Inverted Refux Classifier. Coal Combust. Gasif. Prod. 2015, 7, 40-46. [CrossRef]

60. Vernon, J.H.; Robert, W. Styron Fly Ash Benificiation Process. U.S. Patent 4,121,945, 24 October 1978.

61. Ashworth, R.A.; Rodriguez, L.A.; Padilla, A.A.; Spake, N.B.; Berry, W.W.; Schmeda, R.A. Method for the Recovery of Minerals and Production of by-Products from Coal Ash. U.S. Patent 4,652,433, 24 March 1987.

62. Sahoo, P.K.; Kim, K.; Powell, M.A.; Equeenuddin, S.M. Recovery of metals and other beneficial products from coal fly ash: A sustainable approach for fly ash management. Int. J. Coal Sci. Technol. 2016, 3, 267-283. [CrossRef]

63. Shapiro, M.; Galperin, V. Air classification of solid particles: A review. Chem. Eng. Process. Process Intensif. 2005, 44, 279-285. [CrossRef]

64. Satpathy, H.P.; Patel, S.K.; Nayak, A.N. Development of sustainable lightweight concrete using fly ash cenosphere and sintered fly ash aggregate. Constr. Build. Mater. 2019, 202, 636-655. [CrossRef]

65. Nithyanandam, A.; Deivarajan, T. Development of fly ash cenosphere-based composite for thermal insulation application. Int. J. Appl. Ceram. Technol. 2021, 18, 1825-1831. [CrossRef] 
66. Agrawal, U.S.; Wanjari, S.P. Physiochemical and engineering characteristics of cenosphere and its application as a lightweight construction material-A review. Mater. Today Proc. 2017, 4, 9797-9802. [CrossRef]

67. Kolay, P.K.; Singh, D.N. Physical, chemical, mineralogical, and thermal properties of cenospheres from an ash lagoon. Cem. Concr. Res. 2001, 31, 539-542. [CrossRef]

68. Arizmendi-Morquecho, A.; Chávez-Valdez, A.; Alvarez-Quintana, J. High temperature thermal barrier coatings from recycled fly ash cenospheres. Appl. Therm. Eng. 2012, 48, 117-121. [CrossRef]

69. Brooks, A.L.; Fang, Y.; Shen, Z.; Wang, J.; Zhou, H. Enabling high-strength cement-based materials for thermal energy storage via fly-ash cenosphere encapsulated phase change materials. Cem. Concr. Compos. 2021, 120, 104033. [CrossRef]

70. Rewatkar, M.R.; Shende, D.Z. Experimental investigation on cenosphere-based paper battery and electrochemical battery. Energy Sources Part A Recovery Util. Environ. Eff. 2020, 42, 2018-2033. [CrossRef]

71. Irtiseva, K.; Lapkovskis, V.; Mironovs, V.; Ozolins, J.; Thakur, V.K.; Goel, G.; Baronins, J.; Shishkin, A. Towards Next-Generation Sustainable Composites Made of Recycled Rubber, Cenospheres, and Biobinder. Polymers 2021, 13, 574. [CrossRef]

72. Kushnoore, S.; Kamitkar, N.; Atgur, V.; Uppin, M.S.; Satishkumar, M. A Review on Utilization of Light Weight Fly Ash Cenosphere as Filler in both Polymer and Alloy-Based Composites. J. Mech. Eng. Res. 2020, 3, 17-23. [CrossRef]

73. Bora, P.J.; Porwal, M.; Vinoy, K.J.; Kishore; Ramamurthy, P.C.; Madras, G. Industrial waste fly ash cenosphere composites based broad band microwave absorber. Compos. Part B Eng. 2018, 134, 151-163. [CrossRef]

74. Xu, X.; Li, Q.; Cui, H.; Pang, J.; Sun, L.; An, H.; Zhai, J. Adsorption of fluoride from aqueous solution on magnesia-loaded fly ash cenospheres. Desalination 2011, 272, 233-239. [CrossRef]

75. Gadore, V.; Ahmaruzzaman, M. Tailored fly ash materials: A recent progress of their properties and applications for remediation of organic and inorganic contaminants from water. J. Water Process Eng. 2021, 41, 101910. [CrossRef]

76. Markandeya; Shukla, S.P.; Srivastav, A.L. Removal of Disperse Orange and Disperse Blue dyes present in textile mill effluent using zeolite synthesized from cenospheres. Water Sci. Technol. 2021, 84, 445-457. [CrossRef]

77. Kruger, R. The Use of Cenospheres in Refractories. Energeia 1996, 7, 1-7.

78. Hanif, A.; Lu, Z.; Li, Z. Utilization of fly ash cenosphere as lightweight filler in cement-based composites-A review. Constr. Build. Mater. 2017, 144, 373-384. [CrossRef]

79. Lilkov, V.; Djabarov, N.; Bechev, G.; Petrov, O. Properties and hydration products of lightweight and expansive cements Part II: Hydration products. Cem. Concr. Res. 1999, 29, 1641-1646. [CrossRef]

80. Hanif, A.; Parthasarathy, P.; Ma, H.; Fan, T.; Li, Z. Properties improvement of fly ash cenosphere modified cement pastes using nano silica. Cem. Concr. Compos. 2017, 81, 35-48. [CrossRef]

81. Cabral Pinto, M.M.S.; Silva, M.M.V.G.; Neiva, A.M.R.; Guimarães, F.; Silva, P.B. Release, Migration, Sorption, and (Re)Precipitation of U during Peraluminous Granite Alteration under Oxidizing Conditions in Central Portugal. Geosciences 2018, 8, 95. [CrossRef]

82. Cabral Pinto, M.M.S.; Silva, M.M.V.G.; Neiva, A.M.R. Release, Migration, Sorption and (re)precipitation of U During a Granite Alteration under Oxidizing Conditions. Procedia Earth Planet. Sci. 2014, 8, 28-32. [CrossRef]

83. Ijaola, A.O.; Farayibi, P.K.; Asmatulu, E. Superhydrophobic coatings for steel pipeline protection in oil and gas industries: A comprehensive review. J. Nat. Gas Sci. Eng. 2020, 83, 103544. [CrossRef]

84. Souza, F.; Montedo, O.; Grassi, R.; Antunes, E.G.P. Lightweight high-strength concrete with the use of waste cenosphere as fine aggregate. Matéria 2019, 24. [CrossRef]

85. Alqamish, H.H.; Al-Tamimi, A.K. Development and Evaluation of Nano-Silica Sustainable Concrete. Appl. Sci. 2021, 11, 3041. [CrossRef]

86. Hanif, A.; Diao, S.; Lu, Z.; Fan, T.; Li, Z. Green lightweight cementitious composite incorporating aerogels and fly ash cenospheresMechanical and thermal insulating properties. Constr. Build. Mater. 2016, 116, 422-430. [CrossRef]

87. Brooks, A.L.; Zhou, H.; Hanna, D. Comparative study of the mechanical and thermal properties of lightweight cementitious composites. Constr. Build. Mater. 2018, 159, 316-328. [CrossRef]

88. Chen, Z.; Li, J.; Yang, E. High Strength Lightweight Strain-Hardening Cementitious Composite Incorporating Cenosphere. In Proceedings of the 9th International Conference on Fracture Mechanics of Concrete and Concrete Structures, Berkeley, CA, USA, 28 May-1 June 2016.

89. Senthamarai Kannan, K.; Andal, L.; Shanmugasundaram, M. An Investigation on Strength Development of Cement with Cenosphere and Silica Fume as Pozzolanic Replacement. Adv. Mater. Sci. Eng. 2016, 2016, 9367619. [CrossRef]

90. Ozcivici, E.; Singh, R. Fabrication and Characterization of Ceramic Foams Based on Silicon Carbide Matrix and Hollow AluminoSilicate Spheres. J. Am. Ceram. Soc. 2005, 88, 3338-3345. [CrossRef]

91. Tiwari, V.; Shukla, A.; Bose, A. Acoustic properties of cenosphere reinforced cement and asphalt concrete. Appl. Acoust. 2004, 65, 263-275. [CrossRef]

92. Frigione, M.; Lettieri, M.; Sarcinella, A. Phase Change Materials for Energy Efficiency in Buildings and Their Use in Mortars. Materials 2019, 12, 1260. [CrossRef]

93. Kolay, P.K.; Bhusal, S. Recovery of hollow spherical particles with two different densities from coal fly ash and their characterization. Fuel 2014, 117, 118-124. [CrossRef]

94. Birla, S.; Mondal, D.P.; Das, S.; Kashyap, D.K.; Ch, V.A.N. Effect of cenosphere content on the compressive deformation behaviour of aluminum-cenosphere hybrid foam. Mater. Sci. Eng. A 2017, 685, 213-226. [CrossRef] 
95. Xie, Y.; McAllister, S.; Edwards, D.; Cheng, I. Fabrication of porous hollow glass microspheres. Lancet 2011, 196, 10727-10730. [CrossRef]

96. Deepasree, S.; Venkatraman, V.; Srividya, R. Comparative investigation of internal curing agent incorporated with cenosphere. AIP Conf. Proc. 2020, 2270, 030009. [CrossRef]

97. Liu, F.; Wang, J.; Qian, X.; Hollingsworth, J. Internal curing of high performance concrete using cenospheres. Cem. Concr. Res. 2017, 95, 39-46. [CrossRef]

98. Gupta, N.; Luong, D.D.; Cho, K. Magnesium Matrix Composite Foams—Density, Mechanical Properties, and Applications. Metals 2012, 2, 238-252. [CrossRef]

99. Blissett, R.S.; Rowson, N.A. A review of the multi-component utilisation of coal fly ash. Fuel 2012, 97, 1-23. [CrossRef]

100. Cabral Pinto, M.M.S.; Ferreira da Silva, E.A. Heavy Metals of Santiago Island (Cape Verde) Alluvial Deposits: Baseline Value Maps and Human Health Risk Assessment. Int. J. Environ. Res. Public Health 2018, 16, 2. [CrossRef]

101. Bora, P.J.; Vinoy, K.; Ramamurthy, P.; Kishore; Madras, G. Electromagnetic interference shielding effectiveness of polyaniline-nickel oxide coated cenosphere composite film. Compos. Commun. 2017, 4, 37-42. [CrossRef]

102. Frigione, M.; Lettieri, M.; Sarcinella, A.; Barroso de Aguiar, J.L. Applications of Sustainable Polymer-Based Phase Change Materials in Mortars Composed by Different Binders. Materials 2019, 12, 3502. [CrossRef] [PubMed]

103. Zeng, A.; Xiong, W.; Wang, C.; Zhou, Q. Structure and properties of $\mathrm{BaFe}_{12} \mathrm{O}_{19}$ coated fly ash cenospheres by sol-gel process. J. Wuhan Univ. Technol. Mater. Sci. Ed. 2006, 21, 129-131. [CrossRef]

104. Wimalasiri, V.K.; Weerathunga, H.U.; Kottegoda, N.; Karunaratne, V. Silica Based Superhydrophobic Nanocoatings for Natural Rubber Surfaces. J. Nanomater. 2017, 2017, 2102467. [CrossRef]

105. Breunig, P.; Damodaran, V.; Shahapurkar, K.; Waddar, S.; Doddamani, M.; Jeyaraj, P.; Prabhakar, P. Dynamic impact behavior of syntactic foam core sandwich composites. J. Compos. Mater. 2019, 54, 535-547. [CrossRef]

106. Bora, P.J.; Vinoy, K.J.; Ramamurthy, P.C.; Kishore; Madras, G. Lightweight polyaniline-cobalt coated fly ash cenosphere composite film for electromagnetic interference shielding. Electron. Mater. Lett. 2016, 12, 603-609. [CrossRef]

107. Cardoso, R.J.; Shukla, A.; Bose, A. Effect of particle size and surface treatment on constitutive properties of polyester-cenosphere composites. J. Mater. Sci. 2002, 37, 603-613. [CrossRef]

108. Shukla, S.; Seal, S.; Rahaman, Z.; Scammon, K. Electroless copper coating of cenospheres using silver nitrate activator. Mater. Lett. 2002, 57, 151-156. [CrossRef]

109. Luong, D.; Lehmhus, D.; Gupta, N.; Weise, J.; Bayoumi, M. Structure and Compressive Properties of Invar-Cenosphere Syntactic Foams. Materials 2016, 9, 115. [CrossRef]

110. Afolabi, L.O.; Ariff, Z.M.; Hashim, S.F.S.; Alomayri, T.; Mahzan, S.; Kamarudin, K.-A.; Muhammad, I.D. Syntactic foams formulations, production techniques, and industry applications: A review. J. Mater. Res. Technol. 2020, 9, 10698-10718. [CrossRef]

111. Lisyatnikov, M.; Roshchina, S.; Chukhlanov, V. The use of cenospheres for the production of spheroplastics with high dielectric characteristics, obtained from ash of thermal power plant operating on solid fuel. IOP Conf. Ser. Earth Environ. Sci. 2020, 421, 072005. [CrossRef]

112. Menezes, C.; Rathod, A.P.; Wasewar, K.L. Thermal Conductivity of Fly Ash Cenospheres for Variable Particle Size Ranges. i-Manag J. Mater. Sci. 2016, 4, 19-23.

113. Rajak, D.K.; Pagar, D.D.; Menezes, P.L.; Linul, E. Fiber-Reinforced Polymer Composites: Manufacturing, Properties, and Applications. Polymers 2019, 11, 1667. [CrossRef]

114. Berkowicz, G.; Bradlo, D.; Zukowski, W. Cenospheres as an innovative fluidised bed material. Tech. Trans. Chem. 2016, 2016, 3-10. [CrossRef]

115. Wang, L.; Gao, J.; An, Z.; Zhao, X.; Yao, H.; Zhang, M.; Tian, Q.; Zhai, X.; Liu, Y. Polymer microsphere for water-soluble drug delivery via carbon dot-stabilizing W/O emulsion. J. Mater. Sci. 2019, 54, 5160-5175. [CrossRef]

116. Ploux, L.; Mateescu, M.; Guichaoua, L.; Valentin, J.; Böhmler, J.; Anselme, K.; Champion, E.; Pécout, N.; Chotard-Ghodsnia, R.; Viana, M. New colloidal fabrication of bioceramics with controlled porosity for delivery of antibiotics. J. Mater. Sci. 2016, 51, 8861-8879. [CrossRef]

117. Chen, W.; Qi, Z.; Zhang, L.; Huang, Z. Effects of cenosphere on the mechanical properties of cement-based composites. Constr. Build. Mater. 2020, 261, 120527. [CrossRef]

118. Kristombu Baduge, S.; Mendis, P.; San Nicolas, R.; Nguyen, K.; Hajimohammadi, A. Performance of lightweight hemp concrete with alkali-activated cenosphere binders exposed to elevated temperature. Constr. Build. Mater. 2019, 224, 158-172. [CrossRef]

119. Hajimohammadi, A.; Ngo, T.; Provis, J.L.; Kim, T.; Vongsvivut, J. High strength/density ratio in a syntactic foam made from one-part mix geopolymer and cenospheres. Compos. Part B Eng. 2019, 173, 106908. [CrossRef]

120. Faridi-Majidi, R.; Nezafati, N.; Pazouki, M.; Hesaraki, S. The effect of synthesis parameters on morphology and diameter of electrospun hydroxyapatite nanofibers. J. Aust. Ceram. Soc. 2017, 53, 225-233. [CrossRef]

121. Zheng, Z.; Su, Q.; Zhang, Q.; Ye, H.; Wang, Z. Onion-like carbon microspheres as long-life anodes materials for Na-ion batteries. J. Mater. Sci. 2018, 53, 12421-12431. [CrossRef]

122. Hanif, A.; Usman, M.; Lu, Z.; Cheng, Y.; Li, Z. Flexural fatigue behavior of thin laminated cementitious composites incorporating cenosphere fillers. Mater. Des. 2018, 140, 267-277. [CrossRef]

123. Hanif, A.; Parthasarathy, P.; Lu, Z.; Sun, M.; Li, Z. Fiber-reinforced cementitious composites incorporating glass cenospheresMechanical properties and microstructure. Constr. Build. Mater. 2017, 154, 529-538. [CrossRef] 
124. Zhan, J.; Zhang, H.; Zhu, G. Preparation of photocatalytic cenosphere immobilized with $\mathrm{TiO}_{2}$ nanoparticles by hydrothermal method. J. Ind. Text. 2013, 44, 99-114. [CrossRef]

125. Hanif, A.; Lu, Z.; Sun, M.; Parthasarathy, P.; Li, Z. Green lightweight ferrocement incorporating fly ash cenosphere based fibrous mortar matrix. J. Clean. Prod. 2017, 159, 326-335. [CrossRef]

126. Hanif, A.; Lu, Z.; Diao, S.; Zeng, X.; Li, Z. Properties investigation of fiber reinforced cement-based composites incorporating cenosphere fillers. Constr. Build. Mater. 2017, 140, 139-149. [CrossRef]

127. Wang, J.-Y.; Zhang, M.-H.; Li, W.; Chia, K.-S.; Liew, R.J.Y. Stability of cenospheres in lightweight cement composites in terms of alkali-silica reaction. Cem. Concr. Res. 2012, 42, 721-727. [CrossRef]

128. Blanco, F.; García, P.; Mateos, P.; Ayala, J. Characteristics and properties of lightweight concrete manufactured with cenospheres. Cem. Concr. Res. 2000, 30, 1715-1722. [CrossRef]

129. Liu, F.; Wang, J.; Qian, X. Integrating phase change materials into concrete through microencapsulation using cenospheres. Cem. Concr. Compos. 2017, 80, 317-325. [CrossRef]

130. Majkrzak, G.L.; Watson., J.P.; Brynt, M.M.; Clayton, K. Effect of cenospheres on fly ash brick properties. In Proceedings of the World of Coal Ash, Covington, KY, USA, 7-10 May 2007. 